\title{
Investigating the Impact of Task-based English Language Teaching on Student Competencies at a Saudi EFL Context
}

\author{
Hamza Alshenqeeti *
}

\begin{abstract}
This study examines the impact of task-based English language teaching on Saudi students' competencies, such as reading comprehension and writing proficiency. The mixed-methods approach, involving an experimental component and a qualitative component based on interviews with the participants, is applied in this study. The procedure for the experimental component was developed with attention to the design, implementation, and assessment of task-based English language instruction activities. A growing body of literature suggests that task-based English teaching has gained significance in recent decades because of its perceived relevance in augmenting linguistic and non-linguistic competencies of learners. The study results indicate that the use of tasks in language learning classrooms promotes students' learning, the development of skills in reading and writing, social interaction, and the motivation to use English in real-life situations. These findings can be used to promote language learning in students studying English as a foreign language.
\end{abstract}

Keywords: EFL learner competencies, oral communication, reading comprehension, task-based language teaching (TBLT), writing.

\section{Introduction}

Central to the entire discipline of applied and educational linguistics is the concept of task-based language teaching (TBLT). The adoption of TBLT methods in linguistic instruction has increased over the past few decades (Derakhshan, 2018; Bava and Gheitanchian, 2017). The technique, which has received considerable critical attention, entails the use of pedagogic tasks that learners undertake in the guise of communication to attain forecasted results for evaluation. The tasks can involve opinion gaps in authentic texts performed by students to achieve predetermined objectives (Chorthip, 2018; Derakhshan, 2018; Pierson, 2015). According to Mohammadi and Safdari (2015), TBLT methods provide students with instinctive resources of meaningful content, ideal contexts for communicative activities, and avenues of support to access better opportunities for language use and interaction.

TBLT is a term frequently used in the literature, but to date there is no consensus about its definition. For instance, Mahdieh and Farnaz (2015) refer to TBLT as a set of pedagogical tasks and structured language learning activities that encompass appropriate content, specific working procedures, pre-set objectives, and different outcomes, and they state that such tasks have basic features. Derakhshan (2018), on the other hand, notes that in TBLT, the meaning is supreme and hence participants should construct their own purposes. He goes on further to add that the task should relate to real life, and the outcome should be evaluated. To him, therefore, TBLT is viewed as guaranteeing more successful learning of English in comparison to other methods.

In this paper, the term TBLT will be used in its broadest sense to refer to a work plan that requires pragmatic language consumption to attain an outcome that is assessed following the accuracy and suitability of the content. This is in line with Ellis (2017) who posits that TBLT is a thoroughgoing approach that targets communication, relates to real-world endeavours, prioritises task completion, and assesses outcomes. Thus, assessment forms an integral part of task-based language teaching. Both the consistent student assessment and the feedback framework boost the effectiveness of TBLT.

* Taibah University, Madinah, Saudi Arabia, Saudi Arabia. Received on 10/7/0219 and Accepted for Publication on 25/8/2019. 
Derakhshan (2018) maintains that TBLT has a plethora of alternatives characterised by its fundamental objectives of enhancing the student learning process, establishing learner autonomy, and building self-control strength. In addition, it promotes students' cognitive competencies in an intensive reading course and analytic writing, especially in EFL and ESL classrooms (Ellis, 2017). It is noteworthy that task-based English language teaching encompasses collaborative assessment, which boosts students' self-regulative capacities and learning cognition. The approach encourages a suitable written-plus-spoken feedback framework that enhances students' motivation and language use competence.

The above brief overview shows that TBLT is essential for influencing the improvement of students' competencies at cognitive and language acquisition levels. Nevertheless, there is inconclusive empirical evidence of the practical application of the approach in English teaching practice (Ellis, 2017). According to Pierson (2015), it is essential to integrate communicative tasks systematically to develop EFL learners' speaking competencies. The current study is based on a basic conceptualisation of task-based English language teaching to determine its influence on students' competencies. It attempts to examine the relationship between applying TBLT and changes in students' competencies as well as learners' perceptions of the usefulness of tasks provided according to this approach.

\section{Literature Review and Theoretical Framework}

There is a strong consensus among researchers specialising in second language teaching and acquisition that taskbased language teaching benefits students by providing an opportunity to produce the intended language in meaningful settings. TBLT moves away from traditional teaching approaches and adopts a more communicative framework, encouraging realistic interactions among learners (Yildiz and Senel, 2017). Supporters of collaborative learning emphasise that tasks should be goal-oriented, have several possible outcomes, and permit students to interact with one another during execution beyond their current level of knowledge of the intended language (Bava and Gheitanchian, 2017). Such frameworks ensure that students are involved proactively in the learning process.

The effectiveness of task-based English language teaching has been explored broadly in the field of second language acquisition. Over the past three decades, there has been a surge of interest in task-based language instruction, which is evidenced by multiple published articles, journals, and special issues in English language teaching (Yildiz and Senel, 2017). The growing interest in TBLT has been attributed to the inherent qualities of the tasks it involves, such as a significant focus on meaning, motivation for students to draw on their linguistic and cognitive resources, and goaladaptation concepts; these conditions mandate learners to use language to accomplish real-world tasks (Setayesh and Marzban, 2017). NamazianDost et al. (2017) carried out a study to investigate the effect of TBLT on motivation and grammatical attainment of learners in EFL junior-school classes and reported positive results. The researchers designed activities to assess learners in real-world contexts that mandated the use of English in everyday situations. The study aimed at examining the impact of task-based English language teaching on promoting grammatical proficiency among Iranian junior high school students. The authors report a significant influence of TBLT on grammatical achievement.

Furthermore, task-based language instructional approaches promote the motivation of students to complete assignments related to English language learning. Herraiz Martínez (2018) postulates that task-based education encourages students to learn as well as retain language skills and creativity. In addition to improved grammatical achievement, TBLT plays a central role in enhancing the degree of interactivity, which is an effective way of attaining important educational outcomes by boosting students' motivation to learn and use a foreign language (Bava and Gheitanchian, 2017). Mohammadipour and Rashid (2015) used a cognitive approach to study the effectiveness of TBLT in fostering the oral proficiency of EFL learners. The authors' motivation to carry out the study emanated from the fact that speaking is the most frequently utilised language skill compared to listening, reading, and writing (Mohammadipour and Rashid, 2015). The study reveals positive results and proved that a task-based teaching programmeme grounded in a cognitive framework was useful in fostering learners' speaking proficiency.

There has been extensive research carried out in foreign language settings to determine the impact of TBLT on enhancing learner's competence (Córdoba Zúñiga, 2016; Setayesh and Marzban, 2017). Derakhshan (2018) notes several 
aspects of task-based English language instruction. Notably, teaching should ensure well-adjusted development in various measures of language performance - including accuracy, fluency, and complexity - that contribute to the sustainable progression in students' language abilities. Learners are likely to achieve such complexity if they develop control over newly acquired linguistic skills and integrate them into fluent performance (Ahmed and Bidin, 2016). Furthermore, according to Pierson (2015), task-based English language teaching is effective in enhancing students' speaking and analytic writing skills because it uses real-life activities, such as telling stories, solving problems, and giving directions. Task-based language instruction uses real-world activities that promote situational authenticity (NamazianDost et al., 2017). The emergence of TBLT can be ascribed to the need of language instructors to help learners with both acquisition and knowledge of the language.

Additionally, language educators use the task-based approach to help learners develop their skills and abilities to use language in real-world endeavours. The technique adopts three critical strategies proposed by Martin Bygate: the tasksupported approach, the task-referenced approach, and the task-based approach (Mahdieh and Farnaz, 2015). The tasksupported approach entails the use of tasks to complement prevailing language teaching methods while the taskreferenced tactic utilises tasks to characterise the competencies that students are supposed to acquire after the course (Herraiz Martínez, 2018; Setayesh and Marzban, 2017). In his review of empirical findings on cognitive and sociocognitive perspectives of TBLT, Ellis (2017) stresses the essence of a synergetic connection between practice and research. Most researchers agree that task-based English language teaching represents an innovative scheme to encourage the involvement of teachers in practical classroom demonstrations.

Most researchers tend to adopt Ellis's three-phase model of TBLT, which includes pre-task, during-the-task, and post-task (Chen and Wang, 2019; Lopes, 2015). The pre-test task stage introduces new themes of the task to participants and prepares them with properly organised setting constructions and systems of language; it sets up the task's requirements. Primary activities of the pre-task stage encompass planning, raising awareness, and teaching. In this stage, students have adequate time to plot on the way to carry out a given task (Pierson, 2015). In the pre-task phase, teachers should make learners comprehend the theme. It is worth noting that the whole process of obtaining meaning from texts presents a significant challenge to EFL learners because of their cognitive deficiencies that emanate from the difficulties of processing information in a foreign or second language (Ellis, 2017). According to Chen and Wang (2019), failure to provide adequate background information to EFL or ESL students can prevent them from processing and acquiring a second language.

Such activities are crucial to developing students' receptive skills, self-autonomy, and motivation in high-level reading scenarios. Mohammadipour and Rashid (2015) argue that the phases developed by Ellis are critical to determining the outcomes of task-based English language teaching and, for example, providing EFL and ESL learners with explicit instruction before the task fosters an understanding of spoken language in practical performance. Moreover, Córdoba (2016) stresses the importance of raising awareness in the pre-task stage before involving learners in communicative tasks. Such activities improve students' linguistic, discourse, and pragmatic competencies.

The during-the-task phase showcases the activities being carried out by learners and their requirements during the session. This stage specifies that students should carry out a particular task under time pressure (Herraiz Martínez, 2018). For instance, a task may require students to prepare an in-class presentation within a limited time frame. Each learner is expected to report findings independently while the audience asks questions about any identified grammatical errors, incomplete content in the submission, or logical fallacies (Pierson, 2015). In essence, tasks should be challenging enough to allow students to engage thoughtfully and foster balanced mental processing. Instructors can manipulate the degree of difficulty of the tasks and amend procedures to improve outcomes.

The post-task stage involves a period of feedback and assessment. It features feedback, which underpins the progression of second language writing, speaking, and analytic skills. Feedback plays a leading role in influencing the potential for learning and student motivation (Yildiz and Senel, 2017). The post-task stage focusses on self-regulation, peer evaluation, and teacher assessment. First, students use self-reflection reports to review their performance in the previous stage. Further, learners evaluate their peers' performances (Herraiz Martínez, 2018). In addition, an instructor 
writes an assessment based on three dimensions: comments, language focus, and in-class presentation. Comments adhere to the principle of acknowledgment, approval (praise), and proposals (suggestions) (Yildiz and Senel, 2017). It is essential for teachers to provide valuable recommendations and use affirmative and incentivising language, rather than criticism, to boost students' confidence in undertaking additional tasks. Tasks vary widely depending on the focus of instruction (Ellis, 2017). Teachers can evaluate students on a variety of demonstrable outcomes, including fluency, accuracy, pronunciation, intonation, and sentence structure, as well as confidence and other non-linguistic aspects.

Furthermore, a number of authors have reported analyses of the effect of integrating technology in task-based language teaching approaches to improve learners' competencies. In particular, Bava and Gheitanchian (2017) studied the impact of multimedia TBLT on accuracy, fluency, and oral production. In today's modern era of hyper-digitisation, instructors need to adopt evolving technologies in the design and implementation of task-based language teaching approaches. In the past three decades since the emergence of TBLT, a vast body of studies has reported favourable outcomes on oral language production with limited integration of multimedia technologies. Bava and Gheitanchian (2017) conducted a study to investigate the influence of technology-mediated TBLT on EFL learners' speaking proficiency using different levels of task intricacy. The researchers measured the rate of correct clauses, error-free verbs, and plural forms among Iranian EFL students.

The studies presented thus far provide evidence that instructors can benefit from applying TBLT in their classes in order to develop linguistic skills in students. In view of all that has been mentioned so far, one may suppose that TBLT can provide a solution for many challenges faced in the EFL classroom. However, there is still limited research on the impact of TBLT in developing and enhancing students' competencies. Furthermore, there is a lack of research indicating students' attitudes toward this specific teaching approach, and more research is required in this field.

\section{Research Focus}

\section{Research Questions and Hypotheses}

The research focus of this study examined the relationship between the use of the task-based English language teaching method and changes in students' competencies in reading and writing. It hence seeks to address the following questions:

RQ1: What is the effect of using the task-based English language teaching method on students' competencies in reading and writing?

RQ2: What perceptions do students have regarding task-based English language teaching?

Referring to the research question on the relationship between TBLT and students' competencies to determine the impact of the method with the help of an experimental study, the following hypotheses have been formulated:

$\mathrm{H}_{0}$ : Applying task-based English language teaching has no impact on students' competencies.

$\mathrm{H}_{1}$ : Applying task-based English language teaching has a significant impact on students' competencies.

\section{Participants}

The participants in this study included 30 Saudi students interested in developing their English language competencies. Subjects were recruited using email advertisements. The participating students were selected among the population of 112 students enrolled in an intensive English reading and writing course at the Unified Scientific Track, previously known as the preparatory year programme PYP, in Taibah University. The participants included 15 males and 15 females. All of the participants were aged between 18 and 19 at the beginning of the study. The focus was on selecting those students who had a mean score of 130 out of 150 marks received on their entrance examination in English. In addition, a small sample was chosen because of the expected difficulty of obtaining data from the entire study population.

\section{Instrumentation}

In order to respond to the first research question, it was necessary to conduct an experiment both with methods of pretesting and post-testing students' competencies in relation to their reading and writing and with texts and tasks for the experimental part. The students were provided with protocols for pre-testing their abilities in reading and writing and protocols 
for post-testing these same competencies. The texts for students' work during the experimental stage were on the themes of (a) ethical issues related to nursing homes, (b) the role of diversity in colleges and universities, and (c) the problem of students' employment during study. The tasks were administered by the researcher, who played the role of an instructor.

For the second, qualitative part of this mixed methods research, an interview protocol was used to collect the students' opinions regarding their perceptions of task-based English language teaching. The structured questionnaire included 10 questions on students' thoughts regarding the effect of TBLT on developing their competencies in reading and writing. Thus, the study employed open-ended questions to examine students' particular perceptions on the impact of task-based English language teaching approaches and on changes in their competencies. The participants were interviewed face to face and via phone, and their answers were recorded and transcribed for further use during interpretation.

\section{Procedure}

The experimental part of this research was conducted using a TBLT session for students participating in the experimental group and a general learning session on the same topic for students in the control group. The participants were grouped randomly, as they all demonstrated similar comprehensive learning abilities. Both groups of students received three one-hour sessions during the three-week experimentation period (one session per week). Before participating in these sessions, the participants were asked to complete pre-tests. The sessions for the members of the control group and the experimental group differed only in the presence of tasks for students in the experimental group. Each week, the students were exposed to working with one of the previously listed themes. The session started with a warm-up and brainstorming session. The main activity included the work with the text, reading and writing exercises, and class discussions. The follow-up stage consisted of essays on the set topics and the students' oral presentations.

The sessions for the experimental group followed the same plan, but the main activity part was organised according to the principles of TBLT, with a focus on pre-task, during-the-task, and post-task activities. The work with the text was preceded by questions and answers, and it was associated with completing certain exercises and followed by completing a summary. Teachers are expected to give printed reading materials with several questions or require learners to watch a topic-related video before the lesson (Setayesh and Marzban, 2017). Pre-task activities enable learners to understand and prepare themselves adequately for the task to boost their language competence.

Reading and writing exercises were also introduced and finished according to the TBLT method. Instead of participating in class discussions, students were asked to prepare oral presentations of their opinions regarding the topic. In-class presentations have several primary benefits to both speakers and listeners. For instance, on-the-spot feedback helps learners to identify errors or neglected language rules during the presentation. In addition, such activities are effective in engaging students with each other's work as well as facilitating the development of an audience's logical thinking. In the during-the-task stage, the selection of tasks is a prominent factor that underpins performance. In summary, the students from the experimental group received specific tasks on reading, writing, and oral presentation. After completing three sessions, the participants from both groups completed post-testing, and the focus was on measuring the accuracy and complexity in performing tasks.

When three sessions were completed, the participants from the experimental group took part in individual interview sessions to answer the questions on their perceptions of the sessions. They were also asked to share their opinions regarding any observed changes in their English language competencies. The answers to these questions were further used by the researcher for analysing students' perceptions and responding to the second research question.

\section{Research Methods and Findings}

Statistical significance was analysed using analysis of variance and t-tests as appropriate. Descriptive statistics and the results of $t$-tests were calculated for both groups in order to determine any differences in their performance with reference to the implementation of TBLT for the representatives of the experimental group. The absence of a significant difference between the groups' results before the experiment was determined with a focus on comparing the means for 
the two groups. Table 1, on the next page, presents the descriptive statistics with reference to the scores received after completing the pre-test in reading.

Table 1. Descriptive Statistics of Both Groups on the Reading Pre-Test

\begin{tabular}{|c|c|c|c|c|c|c|c|}
\hline & \multirow{2}{*}{$\mathbf{N}$} & \multirow{2}{*}{ Minimum } & \multirow{2}{*}{ Maximum } & \multirow{2}{*}{ Mean } & \multirow{2}{*}{$\begin{array}{c}\text { St. } \\
\text { Deviation }\end{array}$} & \multicolumn{2}{|c|}{ Skewness } \\
\hline & & & & & & Statistic & Std. Error \\
\hline Experimental & 15 & 5 & 20 & 16.143 & 3.0523 & -.509 & .441 \\
\hline Control & 15 & 3 & 20 & 15.965 & 4.5647 & -.621 & .441 \\
\hline
\end{tabular}

As shown in Table 1, there was no critical difference in the mean scores determined by the reading pre-test for the experimental and control groups (16.143 and 15.965 accordingly). In order to determine the existence of the statistical significance, it was necessary to conduct $t$-tests. Table 2 , on the next page, represents the results of an independent sample $t$-test that was performed for the two groups on their pre-test in reading.

Table 2. Independent Sample t-Test for Both Groups on the Reading Pre-Test

\begin{tabular}{|c|c|c|c|c|c|c|c|c|c|}
\hline & \multicolumn{2}{|c|}{$\begin{array}{c}\text { Levene's Test } \\
\text { for Equality of } \\
\text { Variances }\end{array}$} & \multicolumn{7}{|c|}{ t-test for Equality of Means } \\
\hline & & & & & & & & \multicolumn{2}{|c|}{$\begin{array}{c}95 \% \text { Confidence } \\
\text { Interval of the } \\
\text { Difference } \\
\end{array}$} \\
\hline & $\boldsymbol{F}$ & Sig. & $t$ & Df & $\begin{array}{l}\text { Sig. (2- } \\
\text { tailed) }\end{array}$ & $\begin{array}{c}\text { Mean } \\
\text { Difference }\end{array}$ & $\begin{array}{l}\text { Std. Error } \\
\text { Difference }\end{array}$ & Lower & Upper \\
\hline $\begin{array}{l}\text { Equal } \\
\text { variances } \\
\text { assumed }\end{array}$ & .131 & .004 & .163 & 52 & .007 & .1782 & 1.0456 & -1.987 & 2.294 \\
\hline $\begin{array}{l}\text { Equal } \\
\text { variances not } \\
\text { assumed }\end{array}$ & & & .163 & 51.99 & .007 & .1782 & 1.0456 & -1.987 & 2.294 \\
\hline
\end{tabular}

The results of Levene's test indicate that the $F$ value is .131, where $p=.004<0.05$. Therefore, the variances between the examined groups were significantly different with reference to statistical significance. In addition, the results of the $t$-test, where $t=.163$ and $p=.007<0.05$, indicate that the absence of a particular difference between the mean scores is still statistically significant. Table 3 provides the descriptive statistics details with reference to the scores that were received after completing the post-test in reading.

Table 3. Descriptive Statistics of Both Groups on the Reading Post-Test

\begin{tabular}{|l|l|l|l|l|l|l|l|}
\hline & \multirow{2}{*}{} & N & Minimum & \multirow{2}{*}{ Maximum } & \multirow{2}{*}{ Mean } & \multirow{2}{*}{ St. Deviation } & \multicolumn{2}{|c|}{ Skewness } \\
\cline { 6 - 8 } & & & & & Statistic & Std. Error \\
\hline Experimental & 15 & 8 & 20 & 17.874 & 3.1436 & -.583 & .441 \\
\hline Control & 15 & 6 & 20 & 16.965 & 3.6433 & -.438 & .441 \\
\hline
\end{tabular}

The results indicate that the difference in the mean scores determined for the reading post-test, for both the experimental and control groups (17.874 and 16.965, respectively), was only about 1 point. The $t$-test was conducted in 
order to determine the existence of the statistical significance in these findings. Table 4 includes the results of an independent sample $t$-test that was calculated for the two groups on post-testing in reading.

Table 4. Independent Sample t-Test for Both Groups on the Reading Post-Test

\begin{tabular}{|c|c|c|c|c|c|c|c|c|c|}
\hline & \multicolumn{2}{|c|}{$\begin{array}{c}\text { Levene's Test } \\
\text { for Equality of } \\
\text { Variances }\end{array}$} & \multicolumn{7}{|c|}{ t-test for Equality of Means } \\
\hline & \multirow[b]{2}{*}{$\boldsymbol{F}$} & \multirow[b]{2}{*}{ Sig. } & \multirow[b]{2}{*}{$T$} & \multirow[b]{2}{*}{ Df } & \multirow[b]{2}{*}{$\begin{array}{l}\text { Sig. (2- } \\
\text { tailed) }\end{array}$} & \multirow[b]{2}{*}{$\begin{array}{c}\text { Mean } \\
\text { Difference }\end{array}$} & \multirow[b]{2}{*}{$\begin{array}{l}\text { Std. Error } \\
\text { Difference }\end{array}$} & \multicolumn{2}{|c|}{$\begin{array}{c}\text { 95\% Confidence } \\
\text { Interval of the } \\
\text { Difference } \\
\end{array}$} \\
\hline & & & & & & & & Lower & Upper \\
\hline $\begin{array}{l}\text { Equal } \\
\text { variances } \\
\text { assumed }\end{array}$ & .023 & .001 & 1.145 & 53 & .004 & 0.9091 & 0.2416 & 1.237 & 2.124 \\
\hline $\begin{array}{l}\text { Equal } \\
\text { variances not } \\
\text { assumed }\end{array}$ & & & 1.145 & 52.98 & .004 & 0.9091 & 0.2416 & 1.237 & 2.124 \\
\hline
\end{tabular}

According to the results of Levene's test, the $F$ value is .023 , where $p=.001<0.05$. Thus, the variances between the examined groups were significantly different in this case. The results of the $t$-test, where $t=1.145$ and $p=.004<0.05$, indicate that a particular difference between the mean scores of the two groups of participants is statistically significant. Comparing the results for pre- and post-testing in reading, it is possible to state that the experimental group demonstrated statistically significant improvement in the mean score of about 1.7 points in comparison to the pre-test results and of 0.9 points in comparison to the control group after receiving TBLT. Table 5 provides the descriptive statistics related to the scores that were received by the participants when completing the pre-test in writing.

Table 5. Descriptive Statistics of Both Groups on the Writing Pre-Test

\begin{tabular}{|l|l|l|l|l|l|l|l|}
\hline & $\mathbf{N}$ & \multirow{2}{*}{ Minimum } & \multirow{2}{*}{ Maximum } & \multirow{2}{*}{ Mean } & \multirow{2}{*}{ St. Deviation } & \multicolumn{2}{|c|}{ Skewness } \\
\cline { 6 - 8 } & & & & & Statistic & Std. Error \\
\hline Experimental & 15 & 6 & 20 & 17.135 & 4.2308 & -.456 & .441 \\
\hline Control & 15 & 3 & 20 & 15.278 & 3.4657 & -.335 & .441 \\
\hline
\end{tabular}

Table 5 above lists the results indicating that the difference in the mean scores identified for the writing pre-test for the experimental and control groups (17.135 and 15.278, respectively) was about 2 points. Table 6 provides the results of an independent sample $t$-test that was conducted to examine the statistical significance in the mean score for the two groups on pre-testing in writing. 
Table 6. Independent Sample t-Test for Both Groups on the Writing Pre-Test

\begin{tabular}{|c|c|c|c|c|c|c|c|c|c|}
\hline & \multicolumn{2}{|c|}{$\begin{array}{c}\text { Levene's Test for } \\
\text { Equality of } \\
\text { Variances }\end{array}$} & \multicolumn{7}{|c|}{ t-test for Equality of Means } \\
\hline & & & & & & & & \multicolumn{2}{|c|}{$\begin{array}{c}\text { 95\% Confidence } \\
\text { Interval of the } \\
\text { Difference }\end{array}$} \\
\hline & $\boldsymbol{F}$ & Sig. & $t$ & Df & $\begin{array}{l}\text { Sig. (2- } \\
\text { tailed) }\end{array}$ & $\begin{array}{c}\text { Mean } \\
\text { Difference }\end{array}$ & $\begin{array}{l}\text { Std. Error } \\
\text { Difference }\end{array}$ & Lower & Upper \\
\hline $\begin{array}{l}\text { Equal } \\
\text { variances } \\
\text { assumed }\end{array}$ & .013 & .325 & 1.267 & 54 & .245 & 1.857 & 1.1281 & 1.231 & 2.671 \\
\hline $\begin{array}{l}\text { Equal } \\
\text { variances not } \\
\text { assumed }\end{array}$ & & & 1.267 & 53.89 & .245 & 1.857 & 1.1281 & 1.231 & 2.671 \\
\hline
\end{tabular}

Levene's test indicates that the $F$ value is .013 , where $p=.325>0.05$. Thus, the variances between the examined groups cannot be discussed as significantly different because of the $p$ value. The results of the $t$-test, where $t=1.267$ and $p=.245>$ 0.05 , also indicate that a difference between the mean scores related to the two groups is not statistically significant. Table 7 provides the results of descriptive statistics related to the scores that were received by the participants when completing the post-test tasks in writing.

Table 7. Descriptive Statistics of Both Groups on the Writing Post-Test

\begin{tabular}{|l|c|c|c|c|c|c|c|}
\hline & \multirow{2}{*}{} & N & Minimum & Maximum & Mean & \multirow{2}{*}{$\begin{array}{c}\text { St. } \\
\text { Deviation }\end{array}$} & \multicolumn{3}{|c|}{ Skewness } \\
\cline { 5 - 9 } & & & & & & Statistic & Std. Error \\
\hline Experimental & 15 & 6 & 20 & 17.144 & 3.0611 & -.507 & .441 \\
\hline Control & 15 & 5 & 20 & 14.286 & 3.5677 & -.439 & .441 \\
\hline
\end{tabular}

According to Table 7, there is a noticeable difference in the mean scores identified for the writing post-test for the experimental and control groups (17.144 and 14.286, respectively). Table 8 provides the results of an independent sample $t$-test that was performed for the purpose of examining the statistical significance in the mean score for the two groups on post-testing in writing.

Table 8. Independent Sample t-Test for Two Groups on the Writing Post-Test

\begin{tabular}{|c|c|c|c|c|c|c|c|c|c|}
\hline & \multicolumn{2}{|c|}{$\begin{array}{c}\text { Levene's Test } \\
\text { for Equality of } \\
\text { Variances }\end{array}$} & \multicolumn{7}{|c|}{ t-test for Equality of Means } \\
\hline & & & & & & & & \multicolumn{2}{|c|}{$\begin{array}{c}\text { 95\% Confidence } \\
\text { Interval of the } \\
\text { Difference }\end{array}$} \\
\hline & $\boldsymbol{F}$ & Sig. & $t$ & Df & $\begin{array}{l}\text { Sig. (2- } \\
\text { tailed) }\end{array}$ & $\begin{array}{c}\text { Mean } \\
\text { Difference }\end{array}$ & $\begin{array}{l}\text { Std. Error } \\
\text { Difference }\end{array}$ & Lower & Upper \\
\hline $\begin{array}{l}\text { Equal variances } \\
\text { assumed }\end{array}$ & .126 & .001 & 2.348 & 52 & .001 & 2.858 & 0.6732 & 0.989 & 1.224 \\
\hline $\begin{array}{l}\text { Equal variances not } \\
\text { assumed }\end{array}$ & & & 2.348 & 51.98 & .001 & 2.858 & 0.6732 & 0.989 & 1.224 \\
\hline
\end{tabular}


It was found that the observed variance in the mean scores is statistically significant with an $F$ value of .126, where $p=.001<0.05$. According to the results of the $t$-test, where $t=2.348$ and $p=.001<0.05$, this emphasises the statistical significance of the difference in the calculated mean scores. When drawing conclusions about the impact of TBLT on students' competence in writing, it is possible to observe statistically significant improvements in the participants' mean scores in comparison to the results of the representatives of the control group. As a result of the study, $\mathrm{H}_{0}$ was rejected and $\mathrm{H}_{1}$ was supported by the study findings because of the statistically significant differences determined in students' results related to post-testing in reading and writing competencies.

The results of the conducted interviews were also interpreted in order to provide the answer to the second research question: RQ2 asked, 'what perceptions do students have regarding task-based English language teaching?' The interview questions sought to investigate the students' perceptions of any effects of TBLT on their competencies (reading comprehension and writing). The participants' responses included their ideas, perceptions, attitudes, and visions regarding the following aspects:

Reading:

- $\quad$ Gained more new ideas while reading texts;

- $\quad$ improved understanding and comprehension;

- trained critical thinking;

- $\quad$ enhanced analytical skills;

- extended vision.

Writing:

- Made less [sic] grammatical and lexical mistakes;

- $\quad$ trained to organise written texts in an appropriate manner;

- learned how to use the advanced vocabulary;

- $\quad$ advanced their skills in developing and supporting opinions and ideas.

The participants agreed that TBLT contributed to their learning and understanding; they found that the topics related more to their lives and that the tasks were more motivating for learning the material. They also stated that they developed and improved skills in reading and writing with the help of completing structured tasks. Furthermore, the TBLT approach was viewed as stimulating students' independent work with tasks. Some of the participants found themselves more motivated to learn English as a result of working with the tasks and exercises provided. The collected data indicate that more than half of the participants in the intensive reading course experienced challenges in written self-expression, feared making grammatical mistakes, and were afraid of speaking their viewpoints before undertaking the tasks.

The interview results show that the participants reacted favourably toward the designed tasks. The students acknowledged the authenticity and practical benefits of the tasks in developing their linguistic and non-linguistic abilities, including logical, analytic strategies, teamwork, and strong interpersonal communication. The process of conducting the task promoted the use of the English language and allowed the students to engage in research and interact with one another using English. The study provides evidence regarding the effectiveness of task-based English language teaching in stimulating students' instructional motivations in the learning process. As well, they noted that participation in taskconducting processes aroused and sustained the students' curiosity for new knowledge.

\section{Discussion}

The current study found that TBLT had a significant impact on improving the learners' language competencies in reading and writing. In comparison to the results of the control group, the members of the experimental group succeeded in improving their results in post-testing in reading and writing. The participants' positive attitudes to TBLT and its impact on their competencies was further supported by their statements in the interviews. In particular, the task-based English language instruction helped to reduce the students' anxieties and boost their self-confidence, which are the underlying predictors of developing English language competence. The results show that linguistic confidence can 
contribute to learning in second language learning environments.

Mainly, tasks provide students with more opportunities to train their skills and communicate with group members while making written and oral presentations to the entire class. Such approaches motivate and even inspire students to use English during lessons actively and improve fluency (Pierson, 2015). The study was based on the model by Ellis (2017), which explained the students' success in learning new information with a focus on TBLT, improving reading comprehension, and becoming aware of their unique skills and abilities (Yildiz and Senel, 2017). As such, the learners acquired deep-thinking skills in reading various texts by focusing more closely on the meaning rather than on mastering the English language. In addition, tasks improved the students' writing competence by enhancing logical thinking and their ability to organise ideas in the English language with the help of following hints in tasks.

These results are in line with the findings by many researchers who have studied perspectives of using TBLT in classrooms. Derakhshan (2018) and Bava and Gheitanchian (2017) have noted that complex and challenging tasks contribute to the acquisition of new rules and restructuring of the English language system in reading, writing, and speaking proficiency. According to Pierson (2015), tasks pervade a plethora of features of language teaching research and practice besides having diverse forms under various applications, and they are viewed as closely related to real life. These ideas were supported by the participants' responses to the interview questions. The participants stated that they developed specific skills related to reading and writing as well as skills in critical thinking, organising, and problem solving. According to NamazianDost et al. (2017), learners performing tasks demonstrate improved competency in English grammar. In addition, the approach contributes to increasing the motivation of EFL learners and their language mastery abilities. The use of different types of tasks led to positive outcomes in Iranian EFL learners' improvement in grammar, and these results are correlated with this study's findings.

This study shows that constructing a framework of TBLT and applying a proper assessment system influences the development of learners' competencies in different dimensions, including reading and writing. Overall, the TBLT instruction approach was effective in augmenting learners' competencies, and this idea is supported by Ellis (2017). According to Ellis (2017), instructors succeed when designing tasks using the cognitive method to help learners practice multiple intellectual strategies and processes. Engaging students in pre-task, during-the-task, and post-task stages is critical to promoting positive outcomes in vocabulary, grammar, pronunciation, speaking, and discourse management. The task-based method entails the program being designed using a sequence of tasks that focus on the teaching and learning processes to enhance students' learning (Yildiz and Senel 2017). Additionally, TBLT helps in changing the instructors' role from demanding to dialog organisers and language mentors, which allows learners to share more significant responsibilities in the learning process. Moreover, task-based language instruction enhances students' freedom to express themselves in addition to enhancing their autonomy in the learning process.

\section{Conclusion}

In this investigation, the aim was to assess the impact of task-based English language teaching on students' competencies in EFL settings. One of the more significant findings to emerge from this study is that TBLT used with Saudi students learning English had a positive effect in developing their competencies in reading and writing. These improvements were noticed by students and reported during the interviews. It was also generally shown that TBLT is effective in enhancing interrelationships across the participating students and developing their capacity of self-regulation, improvement, and autonomy. Taken together, these results suggest that TBLT is beneficial for improving both linguistic and non-linguistic competencies.

Despite its exploratory nature, the current study also offers some insight into the TBLT approach and its impact on students' competencies. The findings from the current study make several contributions to the current literature. First, it proposes a framework of the TBLT approach and an assessment system to improve students' competencies with its focus on the impact of TBLT on selected learner proficiencies. Second, it suggests that an effective TBLT lesson should include three phases: pre-task, during-the-task, and post-task. The pre-task phase entails activities which prepare students 
for the main tasks, introduces them to the topic, and provides adequate information to bridge the language gap. The during-the-task stage involves the grouping of students to carry out the tasks. In this stage, the instructor and peers assess the performance of students in a formative evaluation. The post-task stage involves an evaluation exercise, which comprises several components, including comments, class presentations, and language focus.

The current findings add to a growing body of literature on the effectiveness of task-based language instruction in improving learners linguistic and non-linguistic skills. Similar to the context of the current research, most studies cited in this paper were conducted in developing countries, where English is learned as a foreign or a second language. The TBLT approach encompasses crucial components that influence its effectiveness, such as the designing of tasks, student interactions, teamwork, and assessment methods. It is however essential for EFL teachers to provide positive remarks with constructive recommendations to motivate students to partake in future tasks. This study revealed that tasks should display creativity, decision-making, group work, and innovation. Instructors should also consider involving learners in the decision-making in the teaching process to increase their motivation, productivity, and confidence using a new language. In addition, the tasks should be designed to inspire the creation of novel ideas and enhance opportunities for language use.

There is, therefore, a definite need for the use of TBLT to helps learners strengthen organisation methods, critical thinking, interactive communication, and decision-making skills. If we, as EFL practitioners, are to develop a positive learners' attitude towards English language learning, and we have a duty to aim so, then TBLT can by all means be utilised to create an environment for collaborative learning. What is also needed is a cross-level investigation of TBLT use and perception amongst students of various levels, both educationally and linguistically. Further research is also required to determine the efficacy of technology-integrated task-based English language instruction on learners' proficiency.

\section{REFERENCES}

Ahmed, R. Z. and Bidin, S. J. B. (2016) 'The effect of task-based language teaching on writing skills of EFL learners in Malaysia.' Open Journal of Modern Linguistics, 6(3) pp. 207-210.

Bava, M. and Gheitanchian, M. (2017) 'Effects of multimedia task-based teaching and learning approach on EFL learners' accuracy, fluency and complexity of oral production.' Turkish Online Journal of Educational Technology, 16(2) pp. 25-34.

Chen, S. and Wang, J. (2019) 'Effects of task-based language teaching (TBLT) approach and language assessment on students' competencies in intensive reading course.' English Language Teaching, 12(3) pp. 119-150.

Chorthip, V. (2018) 'Using task-based learning with students of academic English.' Arab World English Journal, 9(4) pp. 337-450.

Córdoba Zúñiga, E. (2016) 'Implementing task-based language teaching to integrate language skills in an EFL program at a Colombian university.' Profile: Issues in Teachers' Professional Development, 18(2) pp. 13-24.

Derakhshan, A. (2018) 'The effect of task-based language teaching instruction on the Iranian intermediate EFL learners' writing performance.' International Journal of Instruction, 11(4) pp. 527-544.

Ellis, R. (2017) 'Position paper: moving task-based language teaching forward.' Language Teaching, 50(4) pp. 507-526.

Herraiz Martínez, A. (2018) 'Technology and task-based language teaching (TBLT): exploring pragmatics.' International Journal of Education and Development using Information and Communication Technology, 14(2) pp. 38-61.

Lopes, A. (2015) 'Critical issues in the evaluation of an international project dedicated to technology-mediated TBLT (PETALL).' Teaching English with Technology, 15(2) pp.4-18.

Mahdieh, S. and Farnaz, L. (2015) 'A comparative study of task-based vs. task- supported teaching approaches in an EFL context.' International Journal of Applied Linguistics and English Literature, 4(5) p. 92-98.

Mohammadi, M. and Safdari, N. (2015) 'Pedagogical values of mobile-assisted task-based activities to enhance speaking skill.' In Critical CALL - Proceedings of the 2015 EUROCALL Conference, Padova, Italy. Helm, F., Bradley, L., Guarda, M. and Thouësny, S. (eds) Dublin: Research-publishing.net, pp. 416-420.

Mohammadipour, M. and Rashid, S. M. (2015) 'The impact of task-based instruction program on fostering ESL learners' 
speaking ability: a cognitive approach.’ Advances in Language and Literary Studies, 6(2) pp. 113-126.

NamazianDost, I., Bohloulzadeh, G. and Pazhakh, A. (2017) 'The effect of task-based language teaching on motivation and grammatical achievement of EFL junior high school students.' Advances in Language and Literary Studies, 8(2) pp. $243-259$.

Pierson, S. J. (2015) 'Bridges to Swaziland: using task-based learning and computer-mediated instruction to improve English language teaching and learning.’ Teaching English with Technology, 15(2) pp. 105-119.

Setayesh, M. and Marzban, A. (2017) 'The impact of task-based language teaching on the development of Iranian EFL learners' ESP reading comprehension skills.' Advances in Language and Literary Studies, 8(2) pp. 70-76.

Yildiz, M. and Senel, M. (2017) 'Teaching grammar through task-based language teaching to young EFL learners.' Reading Matrix: An International Online Journal, 17(2) pp. 196-204.

\section{تأثير تدريس اللفة الإنجليزية القائم على المهام في كفاءات الطلاب في محيط لتعلم اللغة الإنجليزية كلغة أجنبية}
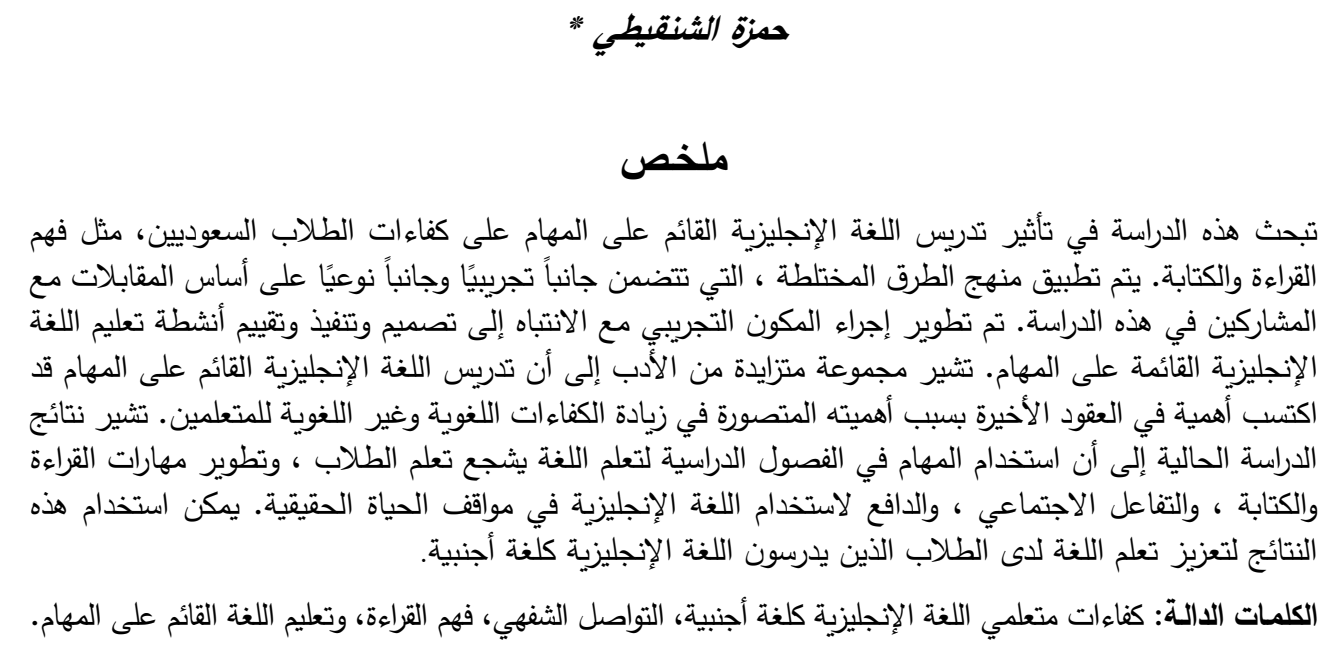

* جامعة طيبة، المدينة المنورة، السعودية. تاريخ استلام البحث 2019/7/10، وتاريخ قبوله 2019/8/25. 